\title{
Risk Management as a Success Factor in the International Activity of Spanish Engineering
}

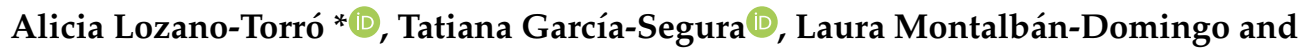 \\ Eugenio Pellicer
}

School of Civil Engineering, Universitat Politècnica de València, 46022 València, Spain; tagarse@upv.es (T.G.-S.); laumondo@upv.es (L.M.-D.); pellicer@upv.es (E.P.)

* Correspondence: allotor@upv.es

Received: 13 January 2019; Accepted: 5 February 2019; Published: 6 February 2019

check for updates

\begin{abstract}
During the period between 2008-2013, the internal market in Spain was characterized by economic crisis, the contraction of the demand experienced in a turbulent business environment, and strong competition among companies. This situation forced many of these companies to work abroad. One of the success factors for Spanish engineering companies abroad has been effective risk management, which avoids compromising the company's objectives, market share, or survival. This article examines the importance of risk management in the success of Spanish engineering consulting firms in the international construction market. Ten executives of Spanish engineering companies with international experience were interviewed, analyzing the importance of risk management for them in the success of internationalization compared with other success factors. The results show that the size of the companies interviewed has no influence on the importance that they gave to risk management, but international experience does relate to the assessment of risk identification and management as a success factor. In addition, companies considered risk management a key factor for optimizing their performance in foreign markets.
\end{abstract}

Keywords: Spanish engineering companies; international market; risk management; success factors

\section{Introduction}

\subsection{Problem Statement}

All over the world, the construction industry has increased due to economic globalization, as well as the improving economies of developing countries (Zhao et al. 2017). However, in recent years, this sector has experienced tensions with the significant reduction in prices of basic metals, which have negatively affected the mining sector, as well as political and financial upheavals that contractors have had to face. The uncertainty that was subsequently generated in the international market has been reflected in the statistics published by the Engineering News Record (ENR 2017), according to which international revenues of the 250 largest international contractors from projects abroad reached $\$ 468.12$ billion in 2016 compared to $\$ 501.14$ billion in 2015. Despite this uncertainty, there are different reasons why construction companies have expanded their business to international markets, such as national market saturation, the distribution of risk, or the use of opportunities abroad (Alashwal et al. 2017). However, it must be taken into account that international projects involve more risks than projects carried out in the national market because they take place in environments characterized by political, economic, social, legal, and cultural differences that will affect the performance of engineering companies (CII 2013; Han et al. 2007a; Javernick-Will and Scott 2010; Jin et al. 2013; Park et al. 2014). Therefore, in this turbulent and highly competitive business environment, it is essential to understand the nature of the performance of 
companies to help them position themselves within the global market and make strategic decisions (Jin et al. 2013). A study conducted by Hwang and Lim (2012) identified 32 key success factors in the context of construction in Singapore, in order to help foreign contractors that wanted to access this country, and noted that "the success of the construction project depends on a combination of factors related to the human being, factors related to the project, factors related to the management of the project, and even factors related to the external environment". In addition, Pal et al. (2017) analyzed the success factors in relationship management in international engineering procurement and construction (IEPC) projects carried out by Chinese companies, and Alashwal et al. (2017) identified the success factors of the internationalization of Malaysian contractors.

One of the most prominent success factors in the literature review is the identification and management of risks (Lee et al. 2015). Since contractors must take into account the different environments surrounding international projects, they must anticipate and identify political, social, and economic risks in the host country and determine how these risks influence the success of their projects (Alashwal et al. 2017). In multicultural environments, risk management in construction projects has acquired a key importance in the last two decades (Razzaq et al. 2018), being one of the factors that makes it possible to increase the value of the company (Zhao et al. 2015) and that leads to obtain potential benefits for companies (Pagach and Warr 2011). For this reason, it is important to analyze the value of the identification and previous analysis of the risks to the companies in their international activity. However, although risk management is a critical success factor for construction companies in international markets, in many cases, these companies do not have sufficient knowledge to carry out external risk management, or they tend to ignore the effects that the lack of external risk management can have on their businesses (Low et al. 2009).

\subsection{Context of Inquiry}

In recent years, the Spanish construction sector has become a world leader due to its international activity, diversification, technical development, and business concentration (Seopan 2016). In the case of Spanish engineering firms, the economic crisis that began in 2007 produced a high contraction in demand, an increase in competition, and high difficulties in accessing financing lines (Tecniberia 2011). This situation was aggravated by the high volume of business and the strong expansion of Spanish engineering companies before the crisis period, causing rigid operating structures and great difficulties in adapting to the reduced market (Tecniberia 2011). This rigidity, along with the inflexibility of labor laws in Spain, caused a lack of activity among the companies for a period of six months, resulting in losses comparable to all of the companies' resources, and with it the technical bankruptcy of these companies. Consequently, Spanish engineering companies adopted two strategies: (1) reducing their productive capacity through Employment Regulation Proceedings, which implied the elimination of the technical resources that had been training for years together with the emigration of trained technicians to other countries; and (2) searching for new business opportunities in the national and international markets. Many Spanish engineering companies chose the latter option; in 2011, over 80\% of firms lacked export activity, and in 2013, the external sector accounted for more than $85 \%$ of the total turnover of companies with international presence, which constituted more than $12 \%$ of the total number of companies in the sector (Tecniberia 2013). In this process, understanding how to measure the success of international projects and conditions affecting this success is critical (Alashwal et al. 2017). In this sense, several studies have been carried out to analyze the internationalization of Spanish engineering companies: García-Canal et al. (2002) studied global alliances as a strategy to accelerate the pace of internationalization; Calderón García et al. (2007) focused on the entry mode choice as part of the internationalization strategy of Spanish companies, and Goñi (2008) identified several variables (reasons, entry modes, competitive advantages, and barriers, among others) of the internationalization of Spanish engineering companies in the period 1993-2008. However, there are no studies that analyze the importance that risk management implies for Spanish engineering companies compared to the rest of the success factors in their internationalization. 


\subsection{Goals of the Research}

To cover this knowledge gap, the following research objectives have been raised. (1) Identify, through a literature review, the success factors that contribute to the increase of the international performance of construction companies, with a special emphasis on effective risk management. (2) Assess the relevance of risk management in the success factors for Spanish engineering companies, through interviews with 10 executives of engineering companies with international experience. The choice of this context is due to different reasons. (a) There have been no previous studies that analyze the importance of risk management within the success factors of Spanish engineering companies. (b) The situation of economic crisis in Spain has caused the necessary and sudden internationalization of these companies. (c) There is an opportunity to access the main data related to the international activity of several Spanish engineering consulting companies.

The results of this research will help companies in the construction industry increase their knowledge of the success factors and include risk management in the definition of strategies related to their international activity.

\section{Research Method}

The first part of the study tries to identify the success factors in the internationalization of construction companies. To do this, grounded theory (Charmaz 2006; Glaser [1978] 2002) has been used to collect and analyze data. This research is part of an exploratory study that does not attempt to develop a theory, but rather uses the model of the concept indicator (Glaser 1978) to collect, code, and categorize the variables found.

The second part of this research aims to analyze the relative importance that the engineering companies provide to risk management with respect to other success factors in a context of economic crisis, as is the case of Spain.

Based on the variables identified in the literature, and for the purpose of their validation, a semi-structured interview (Woodside 2010) was designed as a qualitative research tool and given to 10 executives of Spanish engineering consulting firms. It was chosen for its accessibility through non-probabilistic sampling of convenience and because it was suitable for carrying out exploratory studies such as the one developed in the present investigation (Carrión 2013). The interview comprised two parts: (1) a characterization of the interviewee, and (2) the questions. To determine the importance of the success factors, an 11-point Likert-type scale was used (where $0=$ 'totally disagree' and $10=$ 'totally agree'), which was mainly motivated by the high number of existing variables. The selection of engineering companies has tried to cover different company sizes, turnover volumes, and degrees of internationalization. Another objective has been to interview companies that offer engineering services in different areas of activity and in different countries around the world. Table 1 shows how different characteristics of the companies have been covered by the selected sample:

Table 1. Characteristics of the companies covered by the selected sample. SME: small and medium-sized enterprises.

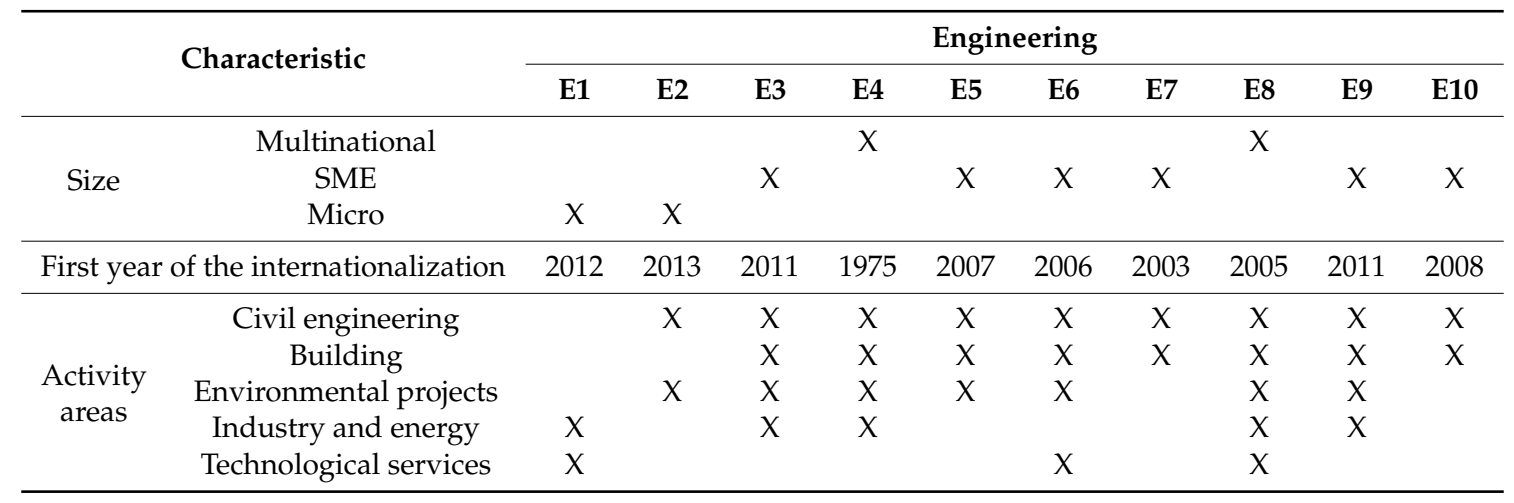


The influence of these characteristics on the importance given by engineering companies to risk management has been already analyzed. Several studies take into account the influence of specific characteristics of companies on their international performance. In the field of corporate finance, the size of a company is considered a fundamental characteristic that affects the results of the research (Dang et al. 2018). For example, Gabaix and Landier (2008) and Gabaix et al. (2014) observed the effect of the size of a company on the differences in salaries of managers according to their competence, concluding that larger companies tend to have more qualified managers (Himmelberg and Hubbard 2000). In the construction sector, Sung et al. (2017) considered the size of a company as one of the factors that influence the relationship between the diversification of activities and the business performance of international contractors. Finally, Panibratov (2009) observed the influence of the international experience of companies on the degree of control over the choice of entry mode into the host country.

Once the 10 interviews were carried out, they were transcribed to a spreadsheet; then, the statistical program SPSS version 24 was used to analyze the data obtained. The reliability of the measurement scale, or the degree to which the measurements are free of random error, was measured by determining its internal consistency with Cronbach's alpha and analyzed for the constructs that constitute the 11-point Likert-type questions. This index is calculated from the correlation between the items using the following formula:

$$
\alpha_{\text {std }}=\mathrm{kp} /(1+\mathrm{p}(\mathrm{k}-1)),
$$

where $\mathrm{k}$ is the number of items, and $\mathrm{p}$ is the average of the linear correlations between each of the items. There will be $2 /(\mathrm{k}(\mathrm{k}-1))$ pairs of correlations. This index presents values between zero and one, considering acceptable values higher than 0.7. Values below 0.7 mean that the instrument being evaluated presents a heterogeneous variability in its items, and therefore will lead us to wrong conclusions. Table 2 shows the result obtained for the Likert question related to success factors (0.94), which is a result that can be considered excellent.

Table 2. Value of Cronbach's alpha for the Likert-type question related to success factors.

\begin{tabular}{cccc}
\hline Construct & Cronbach's Alpha & $\begin{array}{c}\text { Cronbach's Alpha Based on } \\
\text { Standardized Elements }\end{array}$ & No Elements \\
\hline Success factors & 0.940 & 0.938 & 18 \\
\hline
\end{tabular}

\section{Review of Success Factors in International Construction}

In the analysis of internationalization success, the theory of attribution establishes a theoretical basis in which the ability to adapt and expand from one stage to the next in the internationalization of a company is derived from the evaluation and management by the managers of the factors that led to the firm's past successes (Cort et al. 2007). This approach, which is known as critical success factors (CSFs), was first developed by Rockart (1979), who defined CSFs as "areas in which the results, if satisfactory, will guarantee [a] successful competitive performance for the organization". Saraph et al. (1989) considered them "those critical areas of management planning and action that must be practiced to achieve effectiveness". From the perspective of strategic management, traditional success factors include the creation of project teams, the optimization of the capabilities of the general project team, and the adequate management of project risks and their relevant environment, emphasizing cooperative relationships with stakeholders (Cleland and King 1998; Gareis 1991).

Risk management is one of the success factors on which this study is focused, with the aim of determining the importance of this factor for Spanish engineering to obtain international success. In addition, the relative importance of risk management with respect to other success factors will be observed. For this purpose, an extensive literature review related to success in internationalization, and published in the period from 1976 to 2017, has been carried out. In the following sub-sections, each success factor is described and justified. 


\subsection{Identification and Prior Analysis of Risk Factors}

In the first place, it is important to define the terms "risk" and "risk management". According to Lupton (1999), risk in everyday language is used to refer to danger, threat, or harm. Textbooks related to finance define "risk" as a set of results that arise from a decision to which probabilities can be assigned (Watson and Head 1998). Regarding "risk management", this concept is about making informed decisions (Kliem and Ludin 1997). The ISO Guide 73 on risk management vocabulary defines the 'risk management process' as the systematic application of policies, procedures, and management practices to communication activities, consultation, context establishment, and the identification, analysis, evaluation, treatment, monitoring, and review of risks (ISO 2009). The 'establishment of context' implies the identification of external and internal parameters that must be considered in risk management, and determination of the scope and risk criteria for the management policy of risk (Yildiz et al. 2014). The Project Risk Analysis and Management (PRAM) Guide, compiled by members of the Special Interest Group on Risk Management (APM 2007), stated that the implementation of a risk management system helps in a more realistic planning in terms of time and costs, facilitates a greater understanding of the risks, provides a view of the risks that can assistance in decision making, allows a more efficient and effective management of the risks, contributes in the registry of statistical data of historical risks that will help in future actions, and facilitates greater risk taking. Sadgrove (1996) added that risk management helps the company avoid additional costs and interruptions in its activities, and identifies the risks that are worth pursuing and those that should be avoided. According to Jones (2000), risk management can be divided into four stages: (1) identification of the sources of risk, (2) quantification of risk sources, (3) development of the risk response system, and (4) estimation of the residual risk of the project.

In the business environment, the economic uncertainty and the consequences of the global financial crisis have led companies to increase their interest in the management and minimization of risks (Manes-Rossi 2017), for example, by encouraging corporate social responsibility initiatives (Dunbar et al. 2017). In particular, the international activity in the construction sector is sensitive to world events, as they involve political, financial, cultural, and legal risks (Gunhan and Arditi 2005) and cause uncertainty in the host construction markets, negatively affecting the implementation of international projects (Deng et al. 2014). As a result, many studies have examined the importance of risk management in the construction sector. Razzaq et al. (2018) analyzed the main external risks that affect projects carried out by construction companies in Pakistan, with the objective of managing them properly. Hwang et al. (2017) identified and assessed the main risks in the formation of International Construction Joint Ventures (ICJV) and the preferences in the allocation of risks. Liu et al. (2016) explored the risk pathways in international construction projects undertaken by Chinese contractors, and examined the effects of risks on project objectives.

Consequently, risk management has become the central element of successful project management, particularly in an environment of uncertain international construction (Abdelgawad and Fayek 2010), and a key factor in the winning strategies of any company, including international joint ventures (Hsieh et al. 2010). Therefore, effective risk assessment and management will be critical to achieving success in international projects (Zhao et al. 2015; Zhi 1995), thereby constituting an indicator of project performance (Ogunlana 2010). There is a direct relationship between effective risk management and organizational success. Successful risk management not only reduces risk, it also helps to achieve or maintain a competitive advantage to improve the performance of international construction companies (Deng et al. 2014). As an example, the contractor's ability to identify and mitigate technical and programming risks is one of the main factors that influence the technical performance of projects in developing countries (Frimpong et al. 2003; Jafari 2013).

In this way, construction companies must perform a constant analysis of the risks that may arise in their international activity to avoid compromising the company's objectives, market share, or even its long-term stability (Ashley and Bonner 1987). Specifically, the identification of political risks, their quantification, and their management are key factors for the success of internationalization 
in the construction sector (Ashley and Bonner 1987; Baloi and Price 2003). One way to invest in the improvement of risk management is through companies developing a high capacity to obtain scarce and valuable resources, thereby reducing the likelihood and consequences of risks during the implementation of the project (Du et al. 2016). Another way is through the ability to learn and innovate, because they can facilitate the continuous improvement of the level of risk management through the use of advanced techniques, innovative technologies, and optimal management strategies (Du et al. 2016). Finally, partnership allows project members to share information, which will improve communication and enable external organizations to frequently provide valuable information on the operation of risk management (COSO 2004). This in turn can eliminate uncertainties and help contractors make optimal decisions that reduce missed opportunities when addressing project risks (Rahman and Kumaraswamy 2002). In this way, high organizational capacity and better risk management will lead to higher project performances (Du et al. 2016).

\subsection{Public Support for Foreign Direct Investment}

It is essential to create support programs for internationalization to increase the level of international commitment in companies that are already active outside of their borders (Martínez-Maya 2011). A specific case of support to the international activity is the one carried out by the Chinese government to local construction companies (Zhao et al. 2009).

\subsection{Need to Develop an Internationalization Plan}

To address successful internationalization, several authors, such as Franco Lasús (2011), defended the need to prepare an internationalization plan in advance. In the specific case of small and medium-sized enterprises (SMEs), internationalization models establish a gradual process of international activity that will favor their success, starting with entry modes such as direct exportation, and evolving into other entry modes as experience and knowledge are acquired (Martínez-Maya 2011). Experience in international project management is a factor of success in international activity (Gunhan and Arditi 2005). One of the key aspects is the planning of staff availability, because it is not easy to have the right people when they are necessary (Gunhan and Arditi 2005). Long-term financial planning is another aspect to consider (Cheng and Yu 2008; Han et al. 2007a; Korkmaz and Messner 2008), and it will be essential to have control procedures to manage deviations from the plan (Han et al. 2007b).

\subsection{National Sensitivity}

A factor that is considered essential to success in international activity is a company's ability to adapt to the requirements of the destination countries, the most important of which are the government requirements or the preferences of clients (Franco Lasús 2011). To achieve this objective, knowledge of the systems and policies of destination countries will be essential (Jin et al. 2013). Based on Ghoshal and Bartlett's (1990) model of multinational companies, organizations must be sensitive to the local environment and adapt to the diverse locations in which they operate (Javernick-Will 2013). It also will be necessary to establish close interactions with the local society through knowledge of social and cultural customs that may affect the work environment (Adnan et al. 2011). According to Barco (1994), one way to carry out a successful project is to have a manager with international experience and knowledge of the language and cultural customs of the country. From a strategic viewpoint, location is defined as the capacity of an organization to access and use processes, services, and resources in the host country (Wailerdsak and Suehiro 2002). In this way, international contractors will establish a strong link between the project (internal team and stakeholders) and the surrounding local environment through the creation of communication and networking links. Some studies consider the location in the host country as one of the main strategies of the contractor to achieve success in the global market (Jung et al. 2011; Neves and Bugalho 2008). 


\subsection{Ability to Adapt to the Demand of the Sector}

The uniqueness of the services offered and the lack of adaptability to different markets is perceived by managers as an obstacle to success in the international activities of their companies (Cort et al. 2007). Therefore, it is important to develop international activity that is in line with the requirements of the sector of the destination country (Franco Lasús 2011).

\subsection{Right Marketing Campaign}

A factor related to the international success of a company is the amount of money invested in the commercialization of its products (Arditi and Gutierrez 1991), as well as the education, support, and participation of all the employees in the company's marketing plan (Versau 1986). The allocation of more resources to marketing activities, both functionally and operationally, will improve sales growth and allow the company to achieve competitive superiority. In addition, focusing on marketing activities will improve the company's reputation and expand its customer portfolio, thus leading to an increase in sales growth (Ercan and Koksal 2016).

\subsection{High Market Knowledge}

It is important to have the market information in which a company wants to work. One way to obtain it is by hiring the services of a local company that provides them or participating in trade missions organized by associations or even by the government (Gunhan and Arditi 2005). The acquisition of local knowledge is essential to internationalization (Javernick-Will 2013), because entry into the wrong market or at an inappropriate time can lead to failure in international activity (Cheng and Yu 2008; Han et al. 2007a; Korkmaz and Messner 2008). Han et al. (2007a) emphasized the importance of considering differences in the market and collected information from the host countries from the bidding stage to favor obtaining large profits in international construction projects.

\subsection{Global Efficiency}

In international development, a company must have the capacity to improve its competitive advantages, economies of scale, and forms of management, which means that it must have global efficiency (Franco Lasús 2011). In this sense, managers rely on the success of their companies if they are able to improve some competitive advantages, such as the prices of services or the use of economies of scale (Cort et al. 2007).

\subsection{Innovation, Learning, and Transfer}

This variable is related to the capacity for innovation and learning developed by a company and transferred to its subsidiaries or vice versa (Franco Lasús 2011), constituting innovation as a key resource for accessing foreign markets (Cassiman and Golovko 2011; Knight and Cavusgil 2004; Rodríguez and Rodríguez 2005).

\subsection{Organizational Capacity}

According to Madhok (1997), entry in a foreign market is more conditioned by the organizational capacities of a company than by transaction costs, which is why companies that decide to undertake internationalization must pay attention to developing these capacities. Success in a company's international activity involves impregnating, in all the human resources of the different established subsidiaries, the corporate culture or ways of doing business, fostering cohesion and unity (Franco Lasús 2011). One of the main competitive advantages of Chinese companies was to achieve a high degree of organization (Martin et al. 2017). 


\subsection{Continuous Communication with the Customer}

A good relationship with customers is a success factor in relation to obtaining profitability in international projects (Han et al. 2007b). According to Raftery et al. (1998), the ability to maintain long-term relationships with political powers favors the company's success abroad. In some countries, such as those in the Middle East, it is a priority to establish good communications and gain the trust of customers to access the market (Adnan et al. 2011). Likewise, understanding the customer's requirements is a factor that will contribute to the success of an international project, increasing its quality and obtaining customer satisfaction (Ling et al. 2006, 2008).

\subsection{High Previous Experience in the National Market}

To access certain international tenders, it is a fundamental requirement to have or justify previous experience in similar works (Medall Vela 2006). The company's history will contribute to the success of its internationalization (Flanagan 1994; Ling et al. 2005; Zhao and Shen 2008).

\subsection{High Financing Capacity}

If a company has financing capacity, it is likely to increase its international activity (Arditi and Gutierrez 1991). From the viewpoint of the managers, if they perceive a shortage of financial resources, their expectations of achieving success in international activity will fall (Cort et al. 2007). A strong financial capacity of companies will be a key factor for the success of their international activity (Cheng and Yu 2008; Flanagan 1994; Gunhan and Arditi 2005; Han et al. 2007a; Korkmaz and Messner 2008; Ling et al. 2005; Raftery et al. 1998) because, among other aspects, they can withstand delays in customer payments while financing part of the costs.

\subsection{Carry-Over Effect by Large Companies}

In the case of SMEs, their international activity can be favored by following a large client company toward the foreign markets to which it is addressed (Martínez-Maya 2011).

\subsection{Possibility of Access through Joint Ventures}

The investigation of entry strategies in the market is fundamental to the success of international contractors. Establishing alliances is one of the most effective ways to operate in international markets (Alashwal et al. 2017). The formation of joint ventures reduces the risks of international activity, and constituted an important success factor in international companies in the 1980s (Arditi and Gutierrez 1991). Similarly, participation by companies in international networks (Gunhan and Arditi 2005; Raftery et al. 1998) or the disposition of a local partner (Aznar et al. 2017) will favor their international performance.

\subsection{Adequate Selection of Partners in Cases of Contractual Agreements}

When joint investments are established, the critical factors that will condition the success of a project are reputation, trust among partners (Girmscheid and Brockmann 2009; Huemer 2004), experience, personal knowledge, commitment, the management of human resources, and shared objectives (Adnan et al. 2011). If a relationship of trust between partners is established, this can lead to closer collaboration, lower transaction costs, lower risk in the supply chain, and better project performance (Beach et al. 2005; Du et al. 2016; Manu et al. 2015).

\subsection{International Managerial Mentality and International Profile of Human Resources}

One of the components of the managerial function that is considered essential in the competitiveness of a company is the international orientation (Han et al. 2007b), because it constitutes an inexhaustible source of ideas, innovations, and adaptations (Veciana and Genescà 1994), as well as motivation for learning about other cultures (Barco 1994) or cultural intelligence (Ang et al. 2007). 
The role of the management team is key in international activity (D'Angelo et al. 2013; Perlmutter 1969), and it is important to choose managers with expectations of success to assess the company's position in relation to the causal factors of internationalization success and develop strategies to improve the position of the company in the markets (Cort et al. 2007). As an example, in the internationalization of construction companies in Malaysia, a key factor was the international capacity of the entrepreneur (Spence and Crick 2006) to follow the international model of entrepreneurship (Abdul-Aziz and Wong 2010).

On the other hand, the factor related to human resources is considered as important in international activity (Cuervo and Pheng 2003; Dulaimi et al. 2004; Flanagan 1994; Gunhan and Arditi 2005; Ling et al. 2005; Zhao and Shen 2008). Within the programs of support for companies in their internationalization, aspects related to the formation of profiles with an international mentality (Abdul-Aziz et al. 2012) and the compression of cultural diversity are included (Dulaimi et al. 2004). The staff of a company is probably the most important resource in a competitive environment and the key to its success. International construction business requires additional talents in individuals, such as foreign languages, familiarity with the region, the ability to adapt to foreign cultures, and strong emotional characteristics (Gunhan and Arditi 2005).

\subsection{Need to Have A Subsidiary in the Host Country}

According to Ling et al. (2005), one of the entry modes that leads to the success of companies is establishing a subsidiary in the destination country, as well as branches and joint ventures with local companies. There are countries, such Gulf countries, in which international success is conditioned by the establishment of a local office and by maintaining contact with the locals who can act as sponsors of the company in the country (Adnan et al. 2011).

\section{Results and Discussion}

This section presents the results of the interviews and discusses them. In the first place, the characterization data of the companies interviewed are obtained in terms of size, turnover, and activity areas. Regarding the internationalization of companies, they are classified according to their internationalized activity areas, the year in which they started their international activity, and the destination countries where they have accessed. Subsequently, results of the Likert-type question are presented, relating to the importance for the companies of the different success factors and comparing the relative importance that risk management has with respect to the rest of the factors. Finally, the characteristics shared by engineering companies that attach similar importance to risk management as a factor of success in their internationalization have been observed.

\subsection{Sample Characterization}

Table 3 shows the number of employees of each company interviewed, both inside and outside of Spain.

In this research, the number of employees and the annual turnover volume have been used to rank companies by their size, according to Annex I of Regulation (EU) No. 651/2014 of the European Commission (Table 4). The number of employees and total sales are measures of company size that have been used in various studies, such as those related to corporate finance (Dang et al. 2018). Total sales measure competition in the product market, and the number of employees can be used by researchers when the main measures (total assets, total sales, and market value equity) are not available or are irrelevant. Likewise, Hart and Oulton (1996) suggested that choosing which measure to use depends on the availability of the data, as is the case of the present research.

As can be seen from the characterization data and the classification of SMEs (Table 4), two of the companies interviewed are multinationals (E4 and E8), and the rest are SMEs, two of which are microenterprises (E1 and E2). Company E3 could be considered a large company because of the current volume of employees, but it will be treated as an SME due to its turnover and the temporary situation 
that has required a high hiring of personnel to deal with a job abroad. Company E7 was an SME that had to drastically reduce its number of employees due to the economic situation. Finally, company E10 entered into an insolvency procedure in 2014, with a total of 120 employees.

Table 3. Number of employees and turnover: in Spain and abroad.

\begin{tabular}{ccccccc}
\hline \multirow{2}{*}{ Engineering } & \multicolumn{3}{c}{ Number of Employees } & \multicolumn{3}{c}{ Turnover } \\
\cline { 2 - 6 } & In Spain & Abroad & $\begin{array}{c}\text { \% Employees } \\
\text { Abroad }\end{array}$ & National & International & $\begin{array}{c}\text { \% International } \\
\text { Turnover }\end{array}$ \\
\hline E1 & 1 & 0 & 0.0 & 0 & 0 & 0.0 \\
E2 & 1 & 0 & 0.0 & 58,000 & 7000 & 10.8 \\
E3 & 55 & 300 & 84.5 & $1,400,000$ & 300,000 & 17.6 \\
E4 & 1062 & 1419 & 57.2 & $31,000,000$ & $188,000,000$ & 85.8 \\
E5 & 44 & 26 & 37.1 & $2,500,000$ & $5,700,000$ & 69.5 \\
E6 & 84 & 26 & 23.6 & $3,000,000$ & 600,000 & 16.7 \\
E7 & 2 & 0 & 0.0 & 28,444 & 0 & 0.0 \\
E8 & 2100 & 400 & 16.0 & $94,183,477$ & $132,303,240$ & 58.4 \\
E9 & 10 & 0 & 0.0 & 178,175 & 111,967 & 38.6 \\
E10 & 12 & 108 & 0.0 & 300,000 & $5,700,000$ & 95.0 \\
\hline
\end{tabular}

Table 4. Classification of companies (Source: Annex I of Regulation (EU) No. 651/2014 of the European Commission, 2014).

\begin{tabular}{cccc}
\hline Company Category & Staff Headcount & Turnover & Balance Sheet Total \\
\hline Medium-sized & $<250$ & $<=€ 50 \mathrm{~m}$ & $<=€ 43 \mathrm{~m}$ \\
Small & $<50$ & $<=€ 10 \mathrm{~m}$ & $<=€ 10 \mathrm{~m}$ \\
Micro & $<10$ & $<=€ 2 \mathrm{~m}$ & $<=€ 2 \mathrm{~m}$ \\
\hline
\end{tabular}

In terms of turnover, there are four companies in which the volume of external turnover in a year exceed domestic sales (E4, E5, E8, and E10), with percentages ranging between 58-95\% of external turnover. The rest of the companies remain within similar values of international turnover percentage at between $11-18 \%$. Null values correspond to defaults on payments (E7) or newly created companies that do not yet have international turnover (E1).

Regarding international activity, only in two cases is the volume of personnel abroad higher than the national (E3 and E4). This is the case of company E3, which is an example of the phenomenon described in the previous paragraph. In the other companies, the main volume of human resources is maintained in the home country.

Figure 1 shows the services offered by the companies interviewed. The majority of the companies are dedicated to civil engineering $(90 \%)$, followed by companies that carry out activities related to building and urban planning $(80 \%)$, and companies that carry out environmental projects $(70 \%)$.

Another objective of the interview has been to obtain data from companies with different degrees of internationalization. Therefore, one of the questions asked concerned the year of the beginning of their international activity. As can be seen in Table 5, the companies interviewed (E1, E2, E3, E5, and E10) started their international activity once the Spanish economic crisis began, and the rest started their international activity between the years 2003-2006. The early internationalization of the E4 company in 1975 stands out. These results suggest that most companies decided to internationalize because of the economic crisis in Spain in 2007. Some companies decided to go abroad in the previous years in view of the forecasts that announced the arrival of a crisis, while others postponed their international activity at the beginning of this crisis period. 


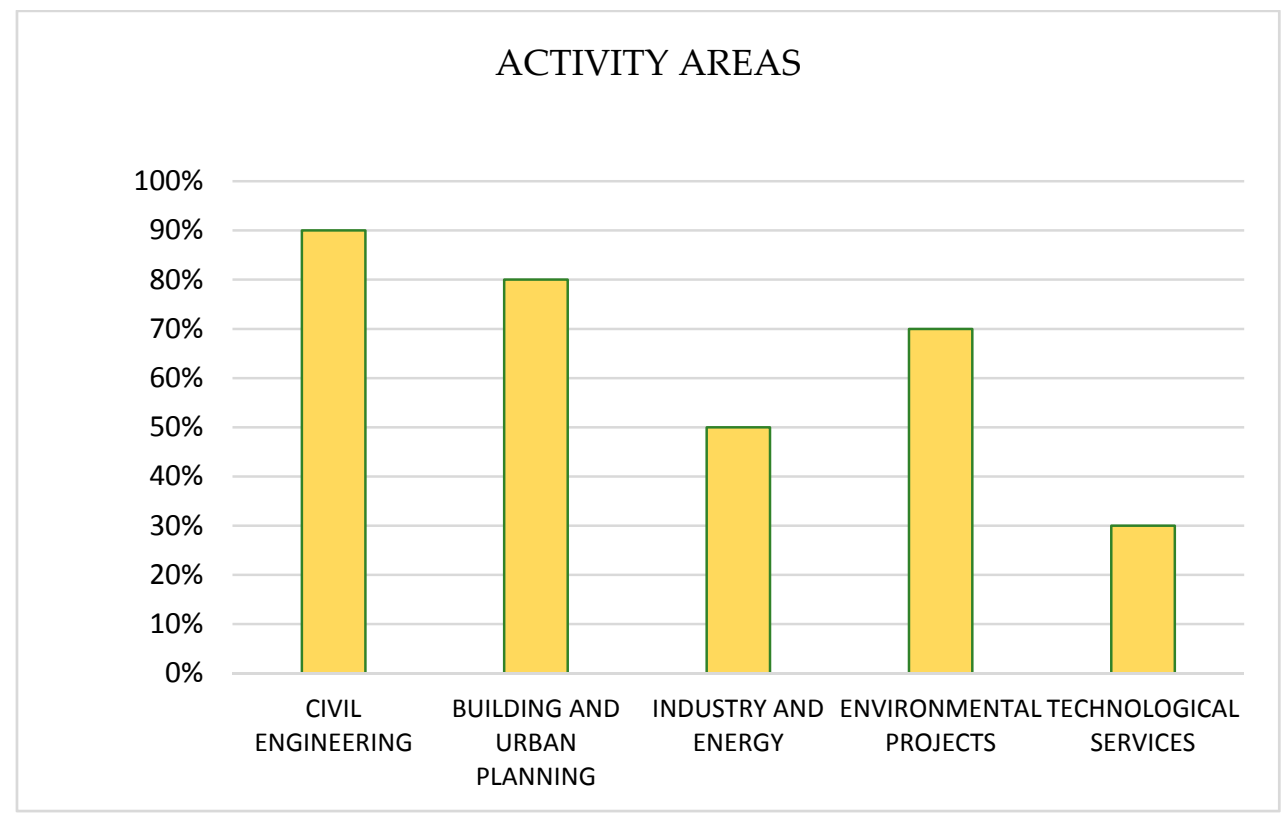

Figure 1. Percentages of activity areas of the companies interviewed.

Table 5. Year of beginning of the international activity of the companies interviewed.

\begin{tabular}{ccccccccccc}
\hline Engineering & E1 & E2 & E3 & E4 & E5 & E6 & E7 & E8 & E9 & E10 \\
\hline $\begin{array}{c}\text { Year of beginning of the } \\
\text { internationalization }\end{array}$ & 2012 & 2013 & 2011 & 1975 & 2007 & 2006 & 2003 & 2005 & 2011 & 2008 \\
\hline
\end{tabular}

Table 6 shows the areas of activity in which the companies interviewed have internationalized, distinguishing between those that have led to better or worse results. Based on the results obtained, the building area is repeated as one of the worst results, because it is a highly regulated activity associated with the particularities of each country. In contrast, conventional areas of civil engineering and technology have led to better results. This is due in large part to the experience and knowledge acquired by companies in the domestic market because they are areas with a high component of specialization and innovation or, in the case of civil engineering, there is high demand in certain destination countries and low implementation costs.

Table 6. Internationalized activity areas and results.

\begin{tabular}{ccc}
\hline \multirow{2}{*}{ Engineering } & \multicolumn{2}{c}{ Activity Areas } \\
\cline { 2 - 3 } & Best Results & Worst Results \\
E1 & Renewable energy &.- \\
E2 & Urban drainage & Hydraulics area \\
E3 & Building technology and transport infrastructure & Architecture \\
E4 & Projects and construction supervision & -- \\
E5 & Roads and urbanizations in developing countries & Large contracts in stable countries \\
E6 & and small contracts in the technological area & with multilateral financing \\
E7 & --- & Building and urbanizations \\
E8 & Industry and energy and civil and infrastructure area & Architecture \\
E9 & --- & Building \\
E10 & Integral projects & Isolated structural calculations \\
\hline
\end{tabular}

Destination countries that the interviewed companies have accessed and that have provided the best and worst results, indicating the reasons, are included in Table 7. From the analysis of the table, 
it can be seen that countries that have provided the worst results are those from North and Central Africa, Romania and Brazil, which was mainly due to issues related to corruption, legal uncertainty, and irregularities, as well as Ecuador for the reduction of the market. For reasons of proximity and language advantage, Latin American countries and Italy stand out, while Saudi Arabia has produced good results due to the valuation of the services received.

Table 7. Destination countries and results.

\begin{tabular}{|c|c|c|}
\hline \multirow{2}{*}{ Engineering } & \multicolumn{2}{|c|}{ Destination Countries } \\
\hline & Best Results (Reasons) & Worst Results (Reasons) \\
\hline E1 & Italy (proximity and better knowledge) & Brazil (legal irregularities) \\
\hline E2 & Colombia (activity area of interest) & \\
\hline E3 & $\begin{array}{l}\text { Latin America (language advantage, need } \\
\text { for qualified technicians, and public works) }\end{array}$ & $\begin{array}{l}\text { Central Africa (high corruption and } \\
\text { legal insecurity) }\end{array}$ \\
\hline $\mathrm{E} 4$ & Saudi Arabia (good valuation of services) & $\begin{array}{l}\text { Libya, Algeria, Kenya (high risks) and } \\
\text { Romania (corruption and legal insecurity) }\end{array}$ \\
\hline E5 & Colombia, Mexico, and Romania & $\begin{array}{l}\text { China (insufficient knowledge of the } \\
\text { country and lack of experience), Morocco } \\
\text { (defaults), and Ecuador } \\
\text { (stoppage of contracts) }\end{array}$ \\
\hline E6 & Colombia, Mexico, Peru, and Algeria & Uzbekistan, Ecuador, and Nicaragua \\
\hline E7 & $-\ldots$ & Algeria \\
\hline E8 & Mexico, Saudi Arabia, and South America & $\begin{array}{l}\text { North Africa (political instability and } \\
\text { cultural difference) }\end{array}$ \\
\hline E9 & --- & $\begin{array}{l}\text { Romania (high corruption), Panama } \\
\text { (impossibility to sign, work is purchased, } \\
\text { not engineering, low fees), and Angola } \\
\text { (legal and citizen insecurity) }\end{array}$ \\
\hline E10 & Georgia, Slovenia, Panama, and Colombia & Saudi Arabia (late payments) \\
\hline
\end{tabular}

\subsection{Importance of Risk Management}

Finally, to analyze the degree of agreement of the companies with the success factors in their internationalization, they were asked an 11-point Likert-type question, where $0=$ 'totally disagree' and $10=$ 'totally agree'. Table 8 shows the responses of each company with respect to each success factors. It shows that companies $\mathrm{E} 4$ and $\mathrm{E} 7$ have given greater importance to management and the identification of risks. Companies E5, E9, and E10 have valued it with eight points.

The profile of the companies that give the best score to the identification and prior analysis of the risks is shown in Table 9, while Table 10 shows the characteristics of the two companies that have scored the lowest risk management. Considering the classification of companies according to the European Commission (Table 4), the companies that have the highest score to risk management are SMEs (E5, E7, E9, and E10) and the multinational E4, while the companies that have the least valued risk management are considered as an SME (E3) and a microenterprise (E2). Considering that the other microenterprise (E1) has awarded seven points to risk management and the other multinational (E8) has valued it with six points, it can be concluded that company size does not seem to influence the valuation of risk management, always taking into account the limitation that the size of the sample obtained implies. 
Table 8. Degree of agreement/disagreement of the companies interviewed regarding the success factors.

\begin{tabular}{|c|c|c|c|c|c|c|c|c|c|c|}
\hline Engineering & E1 & E2 & E3 & E4 & E5 & E6 & E7 & E8 & E9 & E10 \\
\hline Identification and prior analysis of risk factors & 7 & 0 & 5 & 10 & 8 & 6 & 10 & 6 & 8 & 8 \\
\hline Public support for foreign direct investment & 0 & 0 & 1 & 2 & 4 & 4 & 10 & 2 & 0 & 9 \\
\hline Need to develop an internationalization plan & 6 & 0 & 1 & 8 & 8 & 10 & 5 & 6 & 4 & 9 \\
\hline National sensitivity & 7 & 0 & 7 & 10 & 8 & 8 & 10 & 8 & 4 & 10 \\
\hline Ability to adapt to the demand of the sector & 7 & 0 & 6 & 10 & 8 & 6 & 10 & 8 & 2 & 10 \\
\hline Right marketing campaign & 0 & 0 & 2 & 0 & 10 & 4 & 0 & 2 & 1 & 7 \\
\hline High market knowledge & 5 & 0 & 2 & 5 & 8 & 6 & 10 & 7 & 7 & 8 \\
\hline Global efficiency & 7 & 0 & 3 & 5 & 7 & 7 & 7 & 4 & 2 & 7 \\
\hline Innovation, learning, and transfer & 9 & 0 & 3 & 5 & 8 & 6 & 5 & 7 & 7 & 8 \\
\hline Organizational capacity & 8 & 0 & 6 & 10 & 8 & 8 & 5 & 8 & 2 & 9 \\
\hline Continuous communication with the customer & 9 & 0 & 8 & 10 & 9 & 9 & 10 & 9 & 5 & 9 \\
\hline High previous experience in the national market & 10 & 0 & 7 & 5 & 9 & 9 & 10 & 7 & 2 & 6 \\
\hline High financing capacity & 9 & 0 & 2 & 5 & 7 & 9 & 8 & 7 & 10 & 9 \\
\hline Carry-over effect by large companies & 8 & 0 & 1 & 2 & 4 & 9 & 5 & 8 & 8 & 3 \\
\hline Possibility of access through joint ventures & 0 & 0 & 0 & 6 & 4 & 7 & 10 & 4 & 5 & 8 \\
\hline $\begin{array}{l}\text { Adequate selection of partners in case of } \\
\text { contractual agreements }\end{array}$ & 0 & 8 & 6 & 7 & 8 & 9 & 10 & 7 & 7 & 10 \\
\hline $\begin{array}{l}\text { International managerial mentality and } \\
\text { international profile of human resources }\end{array}$ & 8 & 10 & 5 & 10 & 9 & 8 & 8 & 8 & 8 & 10 \\
\hline Need to have a subsidiary in the host country & 4 & 0 & 7 & 8 & 9 & 6 & 8 & 4 & 8 & 7 \\
\hline
\end{tabular}

If the data of the year of initiation of internationalization are observed, then the companies that best score risk management began their internationalization between 2003-2011, apart from company E4, which started an early internationalization in 1975. Among them, those that started their internationalization later (E9 in 2011 and E10 in 2008) have abandoned international activity (E9) or have completely finished their activity as an engineering company (E10). On the other hand, companies that do not consider risk management as important as the previous ones started their internationalization later: in 2011 for company E3, and in 2013 for company E2. In risk management, companies that access the international market must overcome several barriers ( $\mathrm{Du}$ et al. 2016), including: a lack of incentives for better risk management, lack of a formal risk management system, ineffective implementation of risk control strategies, lack of historical data for the analysis of risk trends, and insufficient information of the project for decision making. Based on the results obtained, companies that have internationalized later and do not give importance to risk management may be due to the lack of formal risk management systems in their projects, while companies that value risk management, but experience internationalization late, can be attributed to insufficient knowledge of the international activity to carry out an effective risk management that leads to the success of its internationalization. In addition, it should be considered that this late internationalization has occurred after the beginning of the Spanish crisis in 2007, when companies experienced a significant reduction in their human and financial resources. According to Zhao et al. (2015), this reduction is the main obstacle for implementing a risk management system in companies.

Considering the external turnover data, the companies that least valued risk management had an external turnover of $10.8 \%$ for company E2 and 17.6\% for company E3 compared with the total annual turnover, while companies that awarded the highest score to risk management have percentages between $38.6-95 \%$ of international turnover. A particular case is company E7, which, despite having internationalized before the economic crisis began, did not obtain good results in its international activity, and has not yet achieved external turnover. Due to this, and taking into account again the limitation of the sample size, it seems that the companies that started their internationalization before and have a higher percentage of foreign turnover give more importance to risk management to achieve success in their international activity; therefore, the degree of internationalization of the companies would directly relate to a greater assessment of risk management as a success factor. 
Table 9. Characteristics of the companies that give the highest score to risk management.

\begin{tabular}{cccccc}
\hline Engineering & $\begin{array}{c}\text { Classification } \\
\text { of Companies }\end{array}$ & $\begin{array}{c}\text { External } \\
\text { Turnover (\%) }\end{array}$ & $\begin{array}{c}\text { Year of Beginning of } \\
\text { the Internationalization }\end{array}$ & $\begin{array}{c}\text { Internationalized } \\
\text { Areas with the } \\
\text { Best Results }\end{array}$ & $\begin{array}{c}\text { Destination } \\
\text { Countries with } \\
\text { Best Results }\end{array}$ \\
\hline E4 & Multinational & $85.8 \%$ & 1975 & $\begin{array}{c}\text { Building } \\
\text { technology and } \\
\text { transport } \\
\text { infrastructure }\end{array}$ & Saudi Arabia \\
\hline E5 & SME & $69.5 \%$ & 2007 & $\begin{array}{c}\text { Projects and } \\
\text { supervision of } \\
\text { works }\end{array}$ & $\begin{array}{c}\text { Colombia, } \\
\text { Mexico, and } \\
\text { Romania }\end{array}$ \\
\hline E7 & SME & $0 \%$ & 2003 & & $-\cdots$ \\
\hline E9 & SME & $38.6 \%$ & 2011 & & $-\cdots$ \\
\hline E10 & & & & Integral projects & $\begin{array}{c}\text { Georgia, } \\
\text { Plovenia, } \\
\text { Panama, and } \\
\text { Colombia }\end{array}$ \\
\hline
\end{tabular}

Regarding the best and worst internationalized areas, there are only common characteristics in the two companies that minimize the importance of risk management (E2 and E3) that have obtained better results in hydraulic activities developed in Latin America.

Finally, the other aim of the research is to compare the importance of risk management for the companies interviewed against other success factors. For this, the following descriptive statistics were obtained: mean, median, and standard deviation from the answers to the Likert question related to the success factors (Table 8). Table 11 shows the results obtained, in which it is observed that the five success factors best valued by companies are: (a) training and the international profile of human resources, (b) continuous communication with the client, (c) national sensitivity or ability to adapt to the country of destination, (d) appropriate selection of partners, and (e) identification and previous analysis of risk factors. From a total of 18 success factors in international activity, Spanish engineering companies place risk management in fifth place. Some of the success factors best valued by companies are related to the availability of human resources and trained partners, whose limitation, according to Zhao et al. (2015), implies the difficulty of implementing a risk management system in companies. It is worth mentioning that except for the E2 company, which only considers these two factors important in the achievement of success, companies that have valued the availability of human resources and qualified partners more highly have rated these factors with a maximum of three points more than risk management (E6 company). The rest of the companies have valued them at one or two points more than risk management (E3, E5, E8, and E10 companies). The other two factors that are better valued than risk management are related to the destination country: national sensitivity and communication with the client. However, in a total of 11 points, the E3, E6, E8, and E10 companies have rated the national sensitivity at only two points more than the risk management, and E3, E6, and E8 companies have valued communication with the customer at three more points, which does not mean a high differentiation with respect to the assessment of risk management.

Table 10. Characteristics of the companies that give the lowest score to risk management.

\begin{tabular}{cccccc}
\hline Engineering & $\begin{array}{c}\text { Classification } \\
\text { of Companies }\end{array}$ & $\begin{array}{c}\text { External } \\
\text { Turnover (\%) }\end{array}$ & $\begin{array}{c}\text { Year of Beginning of } \\
\text { the Internationalization }\end{array}$ & $\begin{array}{c}\text { Internationalized } \\
\text { Areas with the } \\
\text { Best Results }\end{array}$ & $\begin{array}{c}\text { Destination } \\
\text { Countries with } \\
\text { Best Results }\end{array}$ \\
\hline E2 & Microenterprise & $10.8 \%$ & 2013 & Urban drainage & Colombia \\
E3 & SME & $17.6 \%$ & 2011 & Hydraulics area & Latin America \\
\hline
\end{tabular}


Table 11. Descriptive statistics of the answers about the success factors.

\begin{tabular}{cccc}
\hline $\begin{array}{c}\text { Descriptive Statistics } \\
\text { Success Factor }\end{array}$ & Mean & Median & Standard Deviation \\
\hline Identification and prior analysis of risk factors & 6.80 & 7.50 & 2.898 \\
Public support for foreign direct investment & 3.20 & 2.00 & 3.645 \\
Need to develop an internationalization plan & 5.70 & 6.00 & 3.302 \\
National sensitivity & 7.20 & 8.00 & 3.120 \\
Ability to adapt to the demand of the sector & 6.70 & 7.50 & 3.401 \\
Right marketing campaign & 2.60 & 1.50 & 3.438 \\
High market knowledge & 5.80 & 6.50 & 2.974 \\
Global efficiency & 4.90 & 6.00 & 2.558 \\
Innovation, learning, and transfer & 5.80 & 6.50 & 2.700 \\
Organizational capacity & 6.40 & 8.00 & 3.204 \\
Continuous communication with the customer & 7.80 & 9.00 & 3.084 \\
High previous experience in the national market & 6.50 & 7.00 & 3.375 \\
High financing capacity & 6.60 & 7.50 & 3.307 \\
Carry-over effect by large companies & 4.80 & 4.50 & 3.293 \\
Possibility of access through joint ventures & 4.40 & 4.50 & 3.534 \\
Adequate selection of partners in case of contractual agreements & 7.20 & 7.50 & 2.860 \\
International managerial mentality and international profile of & 8.40 & 8.00 & 1.506 \\
human resources & 6.10 & 7.00 & 2.726 \\
\hline Need to have a subsidiary in the host country & & \\
\hline
\end{tabular}

\section{Conclusions}

To face the risks and minimize the uncertainty generated by international activity, engineering companies in the construction industry must acquire knowledge of the success factors that have the greatest influence on international activity. Through a review of the literature, 18 success factors have been identified, including the identification and prior analysis of risk factors. Subsequently, with the aim of determining the importance that companies with international activity give to risk management with respect to other success factors, this study particularizes the analysis in Spanish engineering companies with international activity. The situation of economic crisis experienced in Spain since 2007 has caused engineering consulting companies to begin to access the foreign market to ensure their survival. Subsequently, interviews have been conducted with 10 managers of Spanish engineering companies with international activity, in which they have been asked about the importance of the identified success factors for them, and especially the effective risk management. Taking into account the valuation of this factor, it is observed that although the size of the company has not been a determining factor in the valuation, there is a correlation between the international experience of the company interviewed and a better assessment of risk management. Likewise, and in comparison with other factors of success, risk management is the fifth most valued factor, behind the international managerial mentality and international profile of human resources, continuous communication with the client, national sensitivity or ability to adapt to the destination country, and the appropriate selection of partners in the case of contractual agreements.

This research provides a list of 18 internationalization success factors that may be used by companies in their international construction activity. In addition, this research broadens the existing knowledge on the internationalization of Spanish engineering companies by identifying the importance of risk management for the selected sample with respect to the rest of the success factors. Considering the limitation of the size of the selected sample, these results will be especially useful for engineering companies that intend to start in the international market or have little international experience, regarding the implementation of their strategies to obtain international success. Another limitation of the study is the Spanish context, so future research should take into account the particularities of the context that they intend to analyze; although, in similar contexts of economic crisis, the results obtained can be more easily extrapolated. Based on this study, future research could be carried out to further knowledge in risk management systems developed by companies in their international construction activity, and analyze how these systems influence the success of their businesses. 
Author Contributions: Literature review, formal analysis, resources, interviews, data curation and writing (original draft preparation): A.L.-T.; methodology, formal analysis, investigation and resources: T.G.-S.; literature analysis, formal analysis, investigation and data curation: L.M.-D.; conceptualization, methodology, writing (review and editing) and supervision: E.P. All the authors have read and approved the final manuscript.

Funding: This research received no external funding.

Conflicts of Interest: The authors declare no conflict of interest.

\section{References}

Abdelgawad, Mohamed, and Aminah Robinson Fayek. 2010. Risk management in the construction industry using combined fuzzy FMEA and fuzzy AHP. Journal of Construction Engineering and Management 136: 1028-36. [CrossRef]

Abdul-Aziz, Abdul-Rashid, and Sing Sing Wong. 2010. Exploring the internationalization of Malaysian contractors: The international entrepreneurship dimension. Construction Management and Economics 28: 51-61. [CrossRef]

Abdul-Aziz, Abdul-Rashid, Haniza-Azmaya C.M. Nor Azmi, Yuk-Hui Law, and David Ngau Pengiran. 2012. Internationalization of Construction-Related Consultants: Impact of age and size. Journal of Professional Issues in Engineering Education and Practice 139: 148-55. [CrossRef]

Adnan, Hamimah, Heap-Yih Chong, and Roy Morledge. 2011. Success criteria for international joint ventures: The experience of Malaysian contractors in the Middle East. African Journal of Business Management 5: 5254-60.

Alashwal, Ali Mohammed, Nurfarhana Farza Fareed, and Karam Mustafa Al-Obaidi. 2017. Determining success criteria and success factors for international construction projects for Malaysian contractors. Construction Economics and Building 17: 62. [CrossRef]

Ang, Soon, Linn Van Dyne, Christine Koh, K. Yee Ng, Klaus J. Templer, Cheryl Tay, and N. Anand Chandrasekar. 2007. Cultural intelligence: Its measurement and effects on cultural judgment and decision making, cultural adaptation and task performance. Management and Organization Review 3: 335-71. [CrossRef]

APM. 2007. Project Risk Analysis and Management Guide. Special Interest Group on Risk Management, Association for Project Management. Available online: http://www.eurolog.co.uk/apmrisksig/ publications / minipram.pdf (accessed on 19 October 2007).

Arditi, David, and Arturo E. Gutierrez. 1991. Factors affecting US contractors' performance overseas. Journal of Construction Engineering and Management 117: 27-46. [CrossRef]

Ashley, David B., and Joseph J. Bonner. 1987. Political risks in international construction. Journal of Construction Engineering and Management 113: 447-67. [CrossRef]

Aznar, Beltran, Eugenio Pellicer, Steven Davis, and Pablo Ballesteros-Pérez. 2017. Factors affecting contractor's bidding success for international infrastructure projects in Australia. Journal of Civil Engineering and Management 23: 880-89. [CrossRef]

Baloi, Daniel, and Andrew DF Price. 2003. Modelling global risk factors affecting construction cost performance. International Journal of Project Management 21: 261-69. [CrossRef]

Barco, A. L. 1994. International expansion, ethics, and prohibited foreign trade practices. Journal of Management in Engineering 10: 34-40. [CrossRef]

Beach, Roger, Margaret Webster, and Kerrie M. Campbell. 2005. An evaluation of partnership development in the construction industry. International Journal of Project Management 23: 611-21. [CrossRef]

Calderón García, H., T. Fayos Gardo, A. Cervera Taulet, and B. Turbillejas András. 2007. Selección Del Modo De Entrada En Un Mercado Internacional: Valoración De Las Capacidades Empresariales, La Estrategia Empresarial Y La percepción De Los Problemas De La internacionalización. ICE, Revista De Economía 1: 839. Available online: http://www.revistasice.org/index.php/ICE/article/view/1104 (accessed on 31 January 2019).

Carrión, Andrés. 2013. Técnicas Estadísticas de Investigación Social. [Material de clase]. Valencia: Universidad Politécnica de Valencia.

Cassiman, Bruno, and Elena Golovko. 2011. Innovation and internationalization through exports. Journal of International Business Studies 42: 56-75. [CrossRef]

Charmaz, Kathy. 2006. Constructing Grounded Theory: A Practical Guide through Qualitative Analysis. London: Sage. 
Cheng, Hsiang-Lin, and Chow-Ming Joseph Yu. 2008. Institutional pressures and initiation of internationalization: Evidence from Taiwanese small-and medium-sized enterprises. International Business Review 17: 331-48. [CrossRef]

CII (Construction Industry Institute). 2013. Integrated Project Risk Assessment. Austin: Construction Industry Institute. Cleland, David I., and William Richard King, eds. 1998. Project Management Handbook. New York: Van Nostrand Reinhold, vol. 997.

Cort, Kathryn T., David A. Griffith, and D. Steven White. 2007. An attribution theory approach for understanding the internationalization of professional service firms. International Marketing Review 24: 9-25. [CrossRef]

Committee of Sponsoring Organizations of the Treadway Commission (COSO). 2004. Enterprise Risk Management-Integrated Framework. New York: COSO.

Cuervo, Javier C., and Low Sui Pheng. 2003. Ownership advantages/disadvantages of Singapore transnational construction corporations. Construction Management E Economics 21: 81-94.

D'Angelo, Alfredo, Antonio Majocchi, Antonella Zucchella, and Trevor Buck. 2013. Geographical pathways for SME internationalization: insights from an Italian sample. International Marketing Review 30: 80-105. [CrossRef]

Dang, Chongyu, Zhichuan Frank Li, and Chen Yang. 2018. Measuring firm size in empirical corporate finance. Journal of Banking $\mathcal{E}$ Finance 86: 159-76.

Deng, Xiaopeng, Sui Pheng Low, Qiming Li, and Xianbo Zhao. 2014. Developing competitive advantages in political risk management for international construction enterprises. Journal of Construction Engineering and Management 140: 04014040. [CrossRef]

Du, Lei, Wenzhe Tang, Chunna Liu, Shuli Wang, Tengfei Wang, Wenxin Shen, Min Huang, and Yongzhi Zhou. 2016. Enhancing engineer-procure-construct project performance by partnering in international markets: Perspective from Chinese construction companies. International Journal of Project Management 34: 30-43. [CrossRef]

Dulaimi, Mohammed Fadhil, Florence Y. Y. Ling, and George Ofori. 2004. Engines for change in Singapore's construction industry: An industry view of Singapore's Construction 21 report. Building and Environment 39: 699-711. [CrossRef]

Dunbar, Craig G., Zhichuan Frank Li, and Yaqi Shi. 2017. Corporate Social Responsibility and CEO Risk-Taking Incentives. Available online: https:/ / ssrn.com/abstract=2828267 (accessed on 30 January 2019).

ENR (Engineering News-Record). 2017. The Top 250 International Contractors. Troy: Engineering News-Record.

Ercan, Tugce, and Almula Koksal. 2016. Competitive Strategic Performance Benchmarking (CSPB) model for international construction companies. KSCE Journal of Civil Engineering 20: 1657-68. [CrossRef]

Flanagan, R. 1994. The features of successful construction companies in the international construction market. In Etkin Int'l Seminar on Strategic Planning in Construction Companies, Tecnion, Haifa. Israel: CIB WC65 and National Building Research Institute, pp. 304-18.

Franco Lasús, Joan. 2011. Plan de Internacionalización de una ingeniería: Modelo teórico y caso práctico. Doctoral dissertation, Universitat Politècnica de Catalunya, Barcelona, Spain.

Frimpong, Yaw, Jacob Oluwoye, and Lynn Crawford. 2003. Causes of delay and cost overruns in construction of groundwater projects in a developing countries. Ghana as a case study. International Journal of Project Management 21: 321-26. [CrossRef]

Gabaix, Xavier, and Augustin Landier. 2008. Why has CEO pay increased so much? The Quarterly Journal of Economics 123: 49-100. [CrossRef]

Gabaix, Xavier, Augustin Landier, and Julien Sauvagnat. 2014. CEO pay and firm size: An update after the crisis. The Economic Journal 124: F40-F59. [CrossRef]

García-Canal, Esteban, Cristina López Duarte, Josep Rialp Criado, and Ana Valdés Llaneza. 2002. Accelerating international expansion through global alliances: A typology of cooperative strategies. Journal of World Business 37: 91-107. [CrossRef]

Gareis, Roland. 1991. Management by projects: The management strategy of the 'new' project-oriented company. International Journal of Project Management 9: 71-76. [CrossRef]

Ghoshal, Sumantra, and Christopher A. Bartlett. 1990. The multinational corporation as an interorganizational network. Academy of Management Review 15: 603-26. [CrossRef]

Girmscheid, Gerhard, and Christian Brockmann. 2009. Inter-and intraorganizational trust in international construction joint ventures. Journal of Construction Engineering and Management 136: 353-60. [CrossRef] 
Glaser, Barney G. 2002. Conceptualization: On theory and theorizing using grounded theory. International Journal of Qualitative Methods 1: 23-38. First published 1978. [CrossRef]

Glaser, Barney G. 1978. Theoretical sensitivity. In Advances in the Methodology of Grounded Theory. Mill Valley, California: The Sociology Press.

Goñi, Manuel García. 2008. La Internacionalización de los servicios de ingeniería en España. ICE, Revista de Economía 1: 844.

Gunhan, Suat, and David Arditi. 2005. Factors affecting international construction. Journal of Construction Engineering and Management 131: 273-82. [CrossRef]

Han, Seung H., Sang H. Park, Du Y. Kim, Hyoungkwan Kim, and Yun W. Kang. 2007a. Causes of bad profit in overseas construction projects. Journal of Construction Engineering and Management 133: 932-43. [CrossRef]

Han, Seung H., Du Y. Kim, and Hyoungkwan Kim. 2007b. Predicting profit performance for selecting candidate international construction projects. Journal of Construction Engineering and Management 133: 425-36. [CrossRef]

Hart, Peter E., and Nicholas Oulton. 1996. Growth and size of firms. The Economic Journal 106: 1242-52. [CrossRef]

Himmelberg, Charles, and R. Hubbard. 2000. Incentive Pay and the Market for CEOs: An Analysis of Pay-for-Performance Sensitivity. Columbia University Working Paper. Available online: https:/ / papers.ssrn. com/sol3 / papers.cfm?abstract_id=236089 (accessed on 29 January 2019).

Hsieh, Linda HY, Suzana B. Rodrigues, and John Child. 2010. Risk perception and post-formation governance in international joint ventures in Taiwan: The perspective of the foreign partner. Journal of International Management 16: 288-303. [CrossRef]

Huemer, Lars. 2004. Activating trust: The redefinition of roles and relationships in an international construction project. International Marketing Review 21: 187-201. [CrossRef]

Hwang, Bon-Gang, and E-Sin Janicia Lim. 2012. Critical success factors for key project players and objectives: Case study of Singapore. Journal of Construction Engineering and Management 139: 204-15. [CrossRef]

Hwang, Bon-Gang, Xianbo Zhao, and Eileen Wei Yan Chin. 2017. International construction joint ventures between Singapore and developing countries: Risk assessment and allocation preferences. Engineering, Construction and Architectural Management 24: 209-28. [CrossRef]

ISO. 2009. Risk Management-Principles and Guidelines. Geneva: International Organization for Standardization. Available online: http:/ / parsetraining.com/wp-content/uploads/2018/11/BSISO-31000-2009.pdf (accessed on 24 January 2019).

Jafari, Amirhosein. 2013. A contractor pre-qualification model based on the quality function deployment method. Construction Management and Economics 31: 746-60. [CrossRef]

Javernick-Will, Amy N. 2013. Local embeddedness and knowledge management strategies for project-based multi-national firms. Engineering Management Journal 25: 16-26. [CrossRef]

Javernick-Will, Amy N., and W. Richard Scott. 2010. Who needs to know what? Institutional knowledge and global projects. Journal of Construction Engineering and Management 136: 546-57. [CrossRef]

Jin, Zhigang, Fei Deng, Heng Li, and Martin Skitmore. 2013. Practical framework for measuring performance of international construction firms. Journal of Construction Engineering and Management 139: 1154-67. [CrossRef]

Jones, Elden F. 2000. Risk Management-Why? Businesses that fail to acknowledge risk possibilities have their heads stuck in the sand. PM NETWORK 14: 39-42.

Jung, Wooyong, Seung H. Han, Bonsang Koo, and Woosik Jang. 2011. Which strategies are more effective for international contractors during boom and recession periods? Journal of Management in Engineering 28: 281-90. [CrossRef]

Kliem, Ralph L., and Irwin S. Ludin. 1997. Reducing Project Risk. Aldershot: Gower Publishing, Ltd.

Knight, Gary A., and S. Tamar Cavusgil. 2004. Innovation, organizational capabilities, and the born-global firm. Journal of International Business Studies 35: 124-41. [CrossRef]

Korkmaz, Sinem, and John I. Messner. 2008. Competitive positioning and continuity of construction firms in international markets. Journal of Management in Engineering 24: 207-16. [CrossRef]

Lee, K. W., Seung Heon Han, Heedae Park, and H. David Jeong. 2015. Empirical analysis of host-country effects in the international construction market: An industry-level approach. Journal of Construction Engineering and Management 142: 04015092. [CrossRef]

Ling, Florence Yean Yng, C. William Ibbs, and Javier C. Cuervo. 2005. Entry and business strategies used by international architectural, engineering and construction firms in China. Construction Management and Economics 23: 509-20. [CrossRef] 
Ling, Florence Yean, C. William Ibbs, and Wei Yee Hoo. 2006. Determinants of international architectural, engineering, and construction firms' project success in China. Journal of Construction Engineering and Management 132: 206-14. [CrossRef]

Ling, Florence Yean Yng, C. William Ibbs, and Ewen Wei Chew. 2008. Strategies adopted by international architectural, engineering, and construction firms in Southeast Asia. Journal of Professional Issues in Engineering Education and Practice 134: 248-56. [CrossRef]

Liu, Junying, Xianbo Zhao, and Peng Yan. 2016. Risk paths in international construction projects: Case study from Chinese contractors. Journal of Construction Engineering and Management 142: 05016002. [CrossRef]

Low, Sui Pheng, Junying Liu, and Sarah He. 2009. External risk management practices of Chinese construction firms in Singapore. KSCE journal of Civil Engineering 13: 85-95. [CrossRef]

Lupton, D. 1999. WP6: Lead Beneficiary UNIROMA1. London: Risk Routledge.

Madhok, Anoop. 1997. Cost, value and foreign market entry mode: The transaction and the firm. Strategic Management Journal 18: 39-61. [CrossRef]

Manes-Rossi, Francesca. 2017. Reshaping Risk Disclosure through Integrated Reporting: Evidence from Italian Early Adopters. Available online: http:/ /115.248.176.49:8001/jspui/bitstream/123456789/443/1/68951258776-1-PB.pdf (accessed on 25 January 2019).

Manu, Emmanuel, Nii Ankrah, Ezekiel Chinyio, and David Proverbs. 2015. Trust influencing factors in main contractor and subcontractor relationships during projects. International Journal of Project Management 33: 1495-508. [CrossRef]

Martin, Asare, Yousong Wang, Jianfeng Li, and George Mends. 2017. Technical risk factors of international construction. The Journal of Engineering 2018: 138-46. [CrossRef]

Martínez-Maya, José. 2011. Internacionalización del sector de la construcción español, ¿crisis o globalización? Master's thesis, Universitat Politècnica de Catalunya, Barcelona, Spain.

Medall Vela, Francesc. 2006. Estrategias de Internacionalización de las Constructoras Españolas. Available online: https:/ / upcommons.upc.edu/bitstream/handle/2099.1/3304/54112-3.pdf (accessed on 4 January 2019).

Neves, Joao C., and Antonio Bugalho. 2008. Coordination and control in emerging international construction firms. Construction Management and Economics 26: 3-13. [CrossRef]

Ogunlana, Stephen O. 2010. Beyond the 'iron triangle': Stakeholder perception of key performance indicators (KPIs) for large-scale public sector development projects. International Journal of Project Management 28: 228-36.

Pagach, Donald, and Richard Warr. 2011. The characteristics of firms that hire chief risk officers. Journal of Risk and Insurance 78: 185-211. [CrossRef]

Pal, Raktim, Ping Wang, and Xiaopeng Liang. 2017. The critical factors in managing relationships in international engineering, procurement, and construction (IEPC) projects of Chinese organizations. International Journal of Project Management 35: 1225-37. [CrossRef]

Panibratov, A. 2009. Internationalization process of Russian construction industry: Inward investments perspective. Journal for East European Management Studies 14: 210-28. [CrossRef]

Park, Heedae, Kang-Wook Lee, H. David Jeong, and Seung Heon Han. 2014. Effect of institutional risks on the performance of international construction projects. Paper presented at Construction Research Congress 2014: Construction in a Global Network, Atlanta, Georgia, May 19-21, pp. 2126-35.

Perlmutter, Howard. 1969. The tortuous evolution of the multinational corporation. Columbia Journal of World Business 4: 9-18.

Raftery, John, Bernie Pasadilla, Y.H. Chiang, Eddie C.M. Hui, and Bo-Sin Tang. 1998. Globalization and construction industry development: implications of recent developments in the construction sector in Asia. Construction Management \& Economics 16: 729-37.

Rahman, M. Motiar, and Mohan M. Kumaraswamy. 2002. Joint risk management through transactionally efficient relational contracting. Construction Management \& Economics 20: 45-54.

Razzaq, Afia, Muhammad Jamaluddin Thaheem, Ahsen Maqsoom, and Hamza Farooq Gabriel. 2018. Critical external risks in international joint ventures for construction industry in Pakistan. International Journal of Civil Engineering 16: 189-205. [CrossRef]

Rockart, John F. 1979. Chief executives define their own data needs. Harvard Business Review 57: 81-93. [PubMed]

Rodríguez, José López, and Rafael M. García Rodríguez. 2005. Technology and export behaviour: A resource-based view approach. International Business Review 14: 539-57. [CrossRef] 
Sadgrove, Kit. 1996. The Complete Guide to Business Risk Management. London: Routledge.

Saraph, Jayant V., P. George Benson, and Roger G. Schroeder. 1989. An instrument for measuring the critical factors of quality management. Decision Sciences 20: 810-29. [CrossRef]

Seopan. 2016. Actividad Internacional. Available online: https://seopan.es/wp-content/uploads/2016/04/ SEOPAN_Actividad-Internacional-empresas_-1.pdf (accessed on 30 January 2019).

Spence, Martine, and Dave Crick. 2006. A comparative investigation into the internationalisation of Canadian and UK high-tech SMEs. International Marketing Review 23: 524-48. [CrossRef]

Sung, Yoo-Kyung, JeeHee Lee, June-Seong Yi, and JeongWook Son. 2017. Establishment of growth strategies for international construction firms by exploring diversification-related determinants and their effects. Journal of Management in Engineering 33: 04017018. [CrossRef]

Tecniberia. 2011. Desarrollo estratégico del sector de la ingeniería de consulta. Available online: http:/ / www. tecniberia.es/documentos/Desarrollo.pdf (accessed on 3 January 2019).

Tecniberia. 2013. Memoria anual Tecniberia. Available online: http://www.tecniberia.es/documentacion/ Memoria2013_Tecniberia.pdf (accessed on 3 January 2019).

Veciana, Josep $\mathrm{M}^{\mathrm{a}}$, and Enric Genescà. 1994. Management y competitividad en la empresa española. Alta Dirección 30: 21-36.

Versau, Julia A. 1986. Three strategies for sure success: Positioning, action, people are key. Journal of Management in Engineering 2: 191-99. [CrossRef]

Wailerdsak, Natenapha, and Akira Suehiro. 2002. Management localization of a global automobile enterprise case study of toyota motor Thailand. In Globalization, Innovation and Human Resource Development for Competitive Advantage, Proceedings. Bangkok: Asian Institute of Technology.

Watson, Denzil, and Antony Head. 1998. Corporate Finance: Principles and Practice. London: Financial Times Management. Woodside, Arch. 2010. Case Study Research. Theory, metHods and Practice. Bingley: Emerald.

Yildiz, Acelya Ecem, Irem Dikmen, M. Talat Birgonul, Kerem Ercoskun, and Selcuk Alten. 2014. A knowledge-based risk mapping tool for cost estimation of international construction projects. Automation in Construction 43: 144-55. [CrossRef]

Zhao, Zhen Yu, and Li Yin Shen. 2008. Are Chinese contractors competitive in international markets? Construction Management and Economics 26: 225-36. [CrossRef]

Zhao, Zhen Yu, Li Yin Shen, and Jian Zuo. 2009. Performance and strategy of Chinese contractors in the international market. Journal of Construction Engineering and Management 135: 108-18. [CrossRef]

Zhao, Xianbo, Bon-Gang Hwang, and Sui Pheng Low. 2015. Enterprise risk management in international construction firms: Drivers and hindrances. Engineering, Construction and Architectural Management 22: 347-66. [CrossRef]

Zhao, Zhen-Yu, Chao Tang, Xiaoling Zhang, and Martin Skitmore. 2017. Agglomeration and competitive position of contractors in the international construction sector. Journal of Construction Engineering and Management 143: 04017004. [CrossRef]

Zhi, He. 1995. Risk management for overseas construction projects. International Journal of Project Management 13: 231-37. [CrossRef]

(C) 2019 by the authors. Licensee MDPI, Basel, Switzerland. This article is an open access article distributed under the terms and conditions of the Creative Commons Attribution (CC BY) license (http://creativecommons.org/licenses/by/4.0/). 